\section{Degradation of White-Rot Fungi under Nutrient-Rich Conditions}

\author{
Arata Katayama,* Satoko Uchida \\ and Shozo Kuwatsuka
}

\author{
Laboratory of Soil Science, School of Agriculture, \\ Nagoya University, Chikusa-ku, \\ Nagoya 464-01, Japan
}

(Received April 8, 1992; Accepted July 13, 1992)

\section{INTRODUCTION}

Of the wood-rotting fungi, a white-rot fungus Phanerochaete chrysosporium has been reported to degrade a wide spectrum of persistent organochlorine compounds including DDT (1,1,1-trichloro-2, 2-bis(4-chlorophenyl)ethane). ${ }^{1-3)}$ The degrading capability is considered due to a family of lignin-degrading enzymes, collectively referred to as ligninases. It is of great interest to utilize the capability of lignin-degrading fungi for cleanup of contaminated sites and for degradation of xenobiotics in soil.4,5) However, extensive degradation of xenobiotics occurs only under nutrient-limited conditions, since ligninases are secreted by $P$. chrysosporium during the secondary metabolism triggered by nitrogen starvation. ${ }^{6)}$ Ligninases are produced in larger amounts in $100 \% \mathrm{O}_{2}$ culture atmosphere than in the air $\left(21 \% \mathrm{O}_{2}\right) .{ }^{7)}$ If a white-rot fungus is capable of producing ligninases in nutrient-rich conditions as well as in the air, the fungus is expected to degrade xenobiotics under changeable conditions such as in soil. We screened 41 strains of wood-rotting fungi, of which two white-rot fungi degraded the persistent organochlorine compound DDT extensively under both nitrogenlimited and nitrogen-rich conditions as well as in the air.

\section{MATERIALS AND METHODS}

The two fungal isolates used were Phlebia strigoso-zonata 001A and an unidentified woodrotting basidiomycete F7. The former was isolated from rotten wood in the campus of Nagoya

* To whom all correspondence should be addressed.
University and the latter from a rotten wood board kept in the laboratory, which was not identified because it did not form the fruiting body. Phanerochaete chrysosporium BKM F-1767, a gift from Dr. F. Matsumura at University of California, Davis, was also used for comparison.

${ }^{14} \mathrm{C}-\mathrm{DDT}$ (labeled at the phenyl ring, 19.1 $\mathrm{mCi} / \mathrm{mmol}$ ) was purchased from Amersham Japan (Tokyo) and purified just before use by silicagel TLC.

The fungi were incubated in two liquid culture media: the nitrogen-limited medium was composed of $56 \mathrm{~mm}$ of glucose, $0.6 \mathrm{~mm}$ of $\mathrm{NH}_{4} \mathrm{NO}_{3}$, $0.6 \mathrm{~mm}$ of L-asparagine, trace minerals and vitamins in $10 \mathrm{~mm}$ of 2,2-dimethylsuccinate buffer $(\mathrm{pH}=4.5),{ }^{7)}$ and the nitrogen-rich medium of the same composition, except for 10 -fold $\mathrm{NH}_{4} \mathrm{NO}_{3}$. A piece of fungal hyphae was inoculated to $10 \mathrm{ml}$ of nutrient solution in a glass petri dish $(10 \mathrm{~cm}$ in diameter and $5 \mathrm{~cm}$ in height) and incubated at $28^{\circ} \mathrm{C}$ in the dark for 4 days. Then, $3.01 \mathrm{nmol}$ of ${ }^{14} \mathrm{C}-\mathrm{DDT}(125,000 \mathrm{dpm})$ in 5 or $8 \mu \mathrm{l}$ of ethanol solution was added and incubated for 3 weeks. $\mathrm{CO}_{2}$ evolved was trapped in $20 \% \mathrm{KOH}$ solution placed in the petri dish. The KOH solution was changed every 7 days, and the radioactivity was measured by liquid scintillation spectrometry. Volatilized compounds were trapped in polyurethane foam placed in the petri dish. After 3 weeks of incubation, the fungal hyphae were macerated in $30 \mathrm{ml}$ of acetone with a hand homogenizer and extracted with $50 \mathrm{ml}$ of $n$-hexane twice. Radioactivity in the combined hexane extract and the aqueous solution was measured by liquid scintillation spectrometry. The polyurethane foam was extracted with $n$-hexane and the radioactivity was measured in the same manner. The hexane extracts were concentrated and analyzed with a HPTLC (Whatman HPTLC LHP-KDF). The developing solvent was a mixture of $n$-hexane, ether and glacial acetic acid (100:1:1).8) Radioactivity on TLC was measured with a beta-ray scanner (AMBIS Radioanalytic Imaging System).

\section{RESULTS AND DISCUSSION}

Table 1 shows the distribution of radioactivity after 3 weeks of incubation with ${ }^{14} \mathrm{C}-D D T$ in white-rot fungal cultures and the recovery of radioactivity. DDT degradation by the fungi was evaluated by disappearance of DDT, by formation of water-soluble compounds and by $\mathrm{CO}_{2}$ 
Table 1 Distribution of radioactivity after 3 weeks of incubation with ${ }^{14} \mathrm{C}-\mathrm{DDT}$ in white rot fungal cultures and the recovery of radioactivity. ${ }^{\text {a) }}$

\begin{tabular}{|c|c|c|c|c|c|c|c|c|}
\hline \multirow{3}{*}{ Fungi } & \multirow{3}{*}{$\begin{array}{l}\text { Nutrient } \\
\text { nitrogen }\end{array}$} & \multicolumn{5}{|c|}{ Distribution of ${ }^{14} \mathrm{C}$ radioactivity $(\%)$} & & \multirow{3}{*}{$\begin{array}{l}\text { Recovered } \\
{ }^{14} \mathrm{C} \\
\text { radio- } \\
\text { activity } \\
(\%)\end{array}$} \\
\hline & & \multicolumn{3}{|c|}{ Acetone/hexane extracts } & \multirow{2}{*}{$\begin{array}{l}\text { Water } \\
\text { soluble }\end{array}$} & \multirow{2}{*}{$\mathrm{CO}_{2}$} & \multirow{2}{*}{$\begin{array}{l}\text { Volati- } \\
\text { lized }^{\text {b) }}\end{array}$} & \\
\hline & & DDT & DDE & Others & & & & \\
\hline P. chrysosporium & Limited & 23.9 & 7.4 & 14.2 & 17.1 & 0.14 & 30.0 & 92.7 \\
\hline BKM F-1767 & Rich & 44.2 & 8.4 & 8.1 & 19.3 & 0 & 20.8 & 100.8 \\
\hline P. strigoso-zonata & Limited & 21.6 & 9.0 & 16.4 & 23.4 & 0.10 & 28.5 & 99.0 \\
\hline $001 \mathrm{~A}$ & Rich & 7.2 & 3.2 & 7.8 & 46.6 & 0.11 & 36.0 & 100.9 \\
\hline Unidentified & Limited & 17.6 & 5.2 & 8.0 & 48.6 & 0.14 & 16.3 & 95.8 \\
\hline F7 & Rich & 9.6 & 1.1 & 6.7 & 60.8 & 0.22 & 15.9 & 94.3 \\
\hline
\end{tabular}

a) Values are the mean of triplicate experiments. The initial amount of ${ }^{14} \mathrm{C}-\mathrm{DDT}$ was $3.01 \mathrm{nmol}$ in $10 \mathrm{ml}$ culture $(100 \mu \mathrm{g} / l)$.

b) Volatilized compounds from the nitrogen-rich culture of $P$. chrysosporium BKM F-1767 and the cultures of $P$. strigoso-zonata 001A consisted of DDT $(88.7 \%), \mathrm{DDE}(10.1 \%)$ and other hexane extractable compounds $(1.2 \%)$. The composition was almost identical to that of autoclaved cultures. Volatilized compounds from the nitrogen-limited culture of $P$. chrysosporium BKM F-1767 and the cultures of unidentified F7, on the other hand, consisted of DDT (83.7\%), DDE (11.1\%) and other hexane extractable compounds $(5.3 \%)$.

evolution. The proportions of DDT disappearance in $P$. strigoso-zonata 001A and unidentified F7 cultures were higher in the nitrogen-rich medium than in the nitrogen-limited medium, while the proportion in $P$. chrysosporium BKM F-1767 culture was higher under nitrogen-limited conditions, as reported before. ${ }^{2)}$ The proportion of DDT disappearance was higher by $P$. strigosozonata $001 \mathrm{~A}$ and unidentified $\mathrm{F} 7$ than by $P$. chrysosporium BKM F-1767.

More water-soluble fractions were formed in $P$. strigoso-zonata 001A and unidentified F7 cultures than in $P$. chrysosporium BKM F-1767 culture, especially under nitrogen-rich conditions. The proportions of water-soluble fractions in the two fungal isolate cultures were higher under nitrogen-rich conditions, while in the culture of $P$. chrysosporium BKM F-1767, the proportion was not significantly different under the two nutrient conditions.

Less than $1 \%$ of ${ }^{14} \mathrm{C}-\mathrm{DDT}$ was mineralized. In the cultures of $P$. strigoso-zonata $001 \mathrm{~A}$ and unidentified $\mathrm{F} 7,{ }^{14} \mathrm{CO}_{2}$ evolved under nitrogen-rich conditions as well as under nitrogen-limited conditions, while $P$. chrysosporium BKM F-1767 did not mineralize DDT under nutrient-rich conditions.

It was evident that the two white-rot fungi, P. strigoso-zonata 001A and unidentified F7, degraded DDT extensively under both nitrogenlimited and -rich conditions in the air. They had stronger degrading capability than $P$. chryso- sporium BKM F-1767 under the experimental conditions.

In the hexane extracts of $P$. strigoso-zonata 001A and unidentified F7, two metabolites, 1,1dichloro-2,2-bis(4-chlorophenyl)ethylene (DDE) and 2,2,2-trichloro-1,1-bis(4-chlorophenyl)ethanol (dicofol), were identified by co-chromatography. DDE was produced even in an autoclaved fungal culture, which suggested the non-biological formation of DDE. The amount of DDE was smaller in intact cultures, which suggested the degradation of DDE. DDE formation has not been observed under $100 \% \quad \mathrm{O}_{2}$ atmospheric conditions. $^{2)}$ Our results indicated that $\mathrm{DDE}$ was produced in the air $\left(21 \% \mathrm{O}_{2}\right)$. The identification of dicofol indicates that a pathway via dicofol is included in the DDT metabolism by $P$. strigosozonata $001 \mathrm{~A}$ and unidentified F7, as in the one by P. chrysosporium BKM F-1767. ${ }^{2}$ No 1,1-dichloro-2,2-bis(4-chlorophenyl)ethane (DDD) was observed in all the cultures, although $P$. chrysosporium BKM F-1767 has been reported to metabolize DDT to DDD in the early stage of the growth. ${ }^{2)}$ The reason why no DDD was detected in this study might be due to that measurement was done after 3 weeks of incubation.

The two isolates, especially unidentified F7, degraded DDT more extensively than $P$. chrysosporium BKM F-1767 under both nutrient-rich and nutrient-limited conditions as well as in the air. To date, various bacteria and fungi have been reported as DDT degraders, but their de- 
gradation ability was not substantial with the exception of $P$. chrysosporium. ${ }^{9-12)}$ Besides, white-rot fungi has been reported to degrade xenobiotics adsorbed to soil as well as humic acids in soil-suspended culture. ${ }^{4}$ These indicate that the two isolates have a higher potentiality for microbial remediation of contaminated soil. This line of research should be warranted.

\section{ACKNOWLEDGMENTS}

We thank Dr. M. Kimura and Mr. Y. Fujimura in our laboratory for invaluable suggestions and Prof. F. Matsumura at University of California, Davis for a gift of Phanerochaete chrysosporium BKM F-1767.

\section{REFERENCES}

1) J. A. Bumpus, M. Tien, D. Wright \& S. D. Aust: Science 228, 1434 (1985)

2) J. A. Bumpus \& S. D. Aust: Appl. Environ. Microbiol. 53, 2001 (1987)

3) D. C. Eaton: Enzyme Microb. Technol. 7, 194 (1985)

4) K. H. Haider \& J. P. Martin: Soil Biol. Biochem. 20, 425 (1988)

5) A. Katayama \& F. Matsumura: Environ. Sci. Technol. 25, 1329 (1991)

6) M. Tien: CRC Crit. Rev. Microbiol. 15, 141 (1987)

7) T. K. Kirk, E. Schults, W. J. Conners, L. F. Lorenz \& J. G. Zeikus: Arch. Microbiol. 117, 277 (1978)
8) J. P. E. Anderson, E. P. Lichtenstein \& W. F. Whittingham: J. Econ. Entomol. 63, 1595 (1970)

9) J. P. E. Anderson \& E. P. Lichtenstein: Can. J. Microbiol. 17, 1291 (1971)

10) F. Matsumura \& G. M. Boush: J. Econ. Entomol. 61, 610 (1968)

11) M. L. Rochkind-Dubinsky, G. S. Sayler \& J. W. Blackburn: "Microbiological Decomposition of Chlorinated Aromatic Compounds," Marcel Dekker, Inc., New York and Basel, pp. 153-162, 1987

12) R. V. Subba-Rao \& M. Alexander: Appl. Environ. Microbiol. 49, 509 (1985)

\section{要約}

富栄養条件下における白色腐朽菌による DDT の分解

片山新太, 内田聡子，鉔塚昭三

Phanerochaete chrysosporium BKM F-1767 を対照菌株と し ${ }^{14} \mathrm{C}-\mathrm{DDT}$ (芳香環ラベル) を用いて木材腐朽菌 41 株をスク リーニングした結果, 窒素不足条件下だけでなく十分な栄養条 件下でも DDTを生分解できる白色窝朽菌 2 株, Phlebia strigoso-zonata 001A と末同定担糸菌 F7，が得られた．この 2 菌株は, 大気条件下かつ十分な栄養条件下で, DDT を水溶性 物質さらに ${ }^{14} \mathrm{CO}_{2}$ に変換し, その分解能力は Phanerochaete chrysosporium BKM F-1767 を上回った. DDE と dicofol が 代謝産物として同定された。本 2 菌株の生物的環境浄化一の応 用の高い可能性が示唆された. 